\title{
Pengaruh Kualitas Produk, Harga dan Promosi terhadap Keputusan Pembelian Konsumen Sepeda Motor Honda Beat di Dealer MPM Motor Kalisat - Jember
}

\author{
Oleh: \\ Ahmad Fambang Hermawan ${ }^{1}$, Retno Endah Supeni' ${ }^{2}$, Akhmad F. Rozi ${ }^{3}$, \\ ${ }^{1-3}$ Fakultas Ekonomi, Jurusan Manajemen Universitas Muhammadiyah Jember \\ E-mail: ${ }^{1}$ Afambang214@gmail.com, ${ }^{2}$ retnoendahsupeni@yahoo.com, \\ 3fahrurrozi@unmuhjember.ac.id
}

\begin{abstract}
ABSTRAK
Penelitian ini menguji Pengaruh Kualitas Produk, Harga, dan Promosi Terhadap Keputusan Pembelian Konsumen Sepeda Motor Honda Beat di Dealer MPM Motor Kalisat-Jember. Tujuan penelitian adalah untuk mengetahui dan menganalisis pengaruh kualitas produk, harga, dan promosi terhadap keputusan pembelian baik secara parsial maupun simultan. Penelitian dilakukan pada konsumen yang menggunakan Motor Honda Beat di Kecamatan Kalisat. Populasi dalam penelitian ini adalah seluruh pengguna Sepeda Motor Honda Beat di Kecamatan Kalisat sebanyak 100 orang responden. Teknik pengumpulan data menggunakan kuesioner. Analisis yang digunakan meliputi uji instrumen penelitian (uji validitas dan uji reliabilitas), analisis regresi linier berganda, uji asumsi klasik (uji multikolinearitas, uji heteroskedastisitas dan uji normalitas) dan uji hipotesis (uji t, uji $\mathrm{F}$ dan koefisien determinasi). Data diolah menggunakan IBM SPSS 20. Hasil analisis menggunakan regresi dapat diketahui bahwa variabel kualitas produk, harga, dan promosi berpengaruh signifikan terhadap keputusan pemebelian sepeda motor honda beat di kecamatan kalisat.
\end{abstract}

Kata Kunci: Kualitas Produk, Harga, Promosi, Keputusan Pembelian

\section{ABSTRACT}

This study examines the Effect of Product Quality, Prices, and Promotions on Purchasing Decisions of Honda Beat Motorcycle Consumers at the Kalisat-Jember Motor MPM Dealer. The purpose of the research is to find out and analyze the influence of product quality, price, and promotion on purchasing decisions both partially and simultaneously. The study was conducted on consumers who use Honda Beat Motors in the District of Kalisat. The population in this study were all users of Honda Beat Motorbikes in the District of Kalisat as many as 100 respondents. The technique of collecting data using a questionnaire. The analysis used included the research instrument test (validity and reliability test), multiple linear regression analysis, classic assumption test (multicollinearity test, heteroscedasticity test and normality test) and hypothesis testing (t test, F test and coefficient of determination). Data is processed using IBM SPSS 20. The results of the analysis using regression can be seen that the variables of product quality, price, and promotion have a significant effect on the decision to buy Honda Beat motorbikes in Kalisat sub-district.

Key Words: Product Quality, Price, Promotion, Buying Decision

\section{I.PENDAHULUAN}

\subsection{Latar Belakang}

Pada saat ini kebutuhan sepeda motor bagi masyarakat menjadi hal yang sangat penting mengingat tingginya kemacetan yang ada di jalan raya, menjadi salah satu alternatif untuk mempermudah dan kelancaran untuk mencapai suatu tujuan di dalam kota. Permintaan masyarakat terhadap sepeda motor terus mengalami peningkatan, hal ini memberikan peluang bagi para produsen sepeda motor untuk melakukan inovasi dari produk yang dihasilkannya. 
Ketertarikan pemilihan merek tersebut karena produk sepeda motor semakin banyak diminati oleh kalangan masyarakat. Keunggulan teknologi motor Honda diakui di seluruh dunia dan telah dibuktikan dalam berbagai kesempatan. Honda pun mengembangkan teknologi yang mampu menjawab kebutuhan pelanggan yaitu mesin "bandel" dan irit bahan bakar, sehingga menjadikannya sebagai pelopor kendaraan roda dua yang ekonomis.

Untuk memperkuat market share di pasar motor matic, PT. Astra Honda Motor meluncurkan produk matic yaitu Honda Vario 125, Vario $110 \mathrm{CW}$, Beat, Spacy dan Honda Scoopy. Kualitas produk merupakan pemahaman bahwa produk yang ditawarkan oleh penjual mempunyai nilai jual lebih yang tidak dimiliki oleh produk pesaing (Kotler dan Amstrong, 2008)

Harga adalah kecenderungan konsumen untuk menggunakan harga dalam memberi penilaian tentang kualitas produk (Burton et al., 1998, Sinha and Batra, 1999-2000, Garretson et al., 2002). Kotler \& Keller (2009) menyatakan bahwa Promosi adalah menginformasikan, mempengaruhi dan membujuk serta mengingatkan konsumen tentang perusahaan dan produknya.

Tujuan melakukan promosi dapat dihubungkan dengan peran khusus setiap komponen dalam pemasaran. Promosi penjualan seperti pameran dapat digunakan untuk mencapai berbagai tujuan dalam bauran promosi (Shimp \& Terence, 2003). Sedangkan menurut Kotler dan Keller (2009) keputusan pembelian adalah suatu proses penyelesaian masalah yang terdiri dari menganalisa atau pengenalan kebutuhan dan keinginan, pencarian informasi, penilaian sumber-sumber seleksi terhadap alternatif pembelian, keputusan pembelian dan perilaku setelah pembelian.

Motor matic merek Honda lebih cenderung diminati oleh masyarakat Indonesia. Apalagi dengan munculnya produk Honda baru yaitu Honda Beat. Honda Beat adalah sepeda motor yang berjenis skuter matic yang sudah langsung menarik minat konsumen, karena Honda Beat berjenis matic ini mempunyai kualitas mesin terbaik. Bukan hanya mesinnya saja tetapi cara menggunakan kendaraan sepeda motor Honda Beat ini juga tidak susah. Laki - laki bahkan perempuan pun pasti akan dapat mengendarai sepeda motor ini. Konsumen yang mengendarai produk baru ini juga dapat mengendarainya dengan nyaman karena produk terbaru Honda ini memiliki sandaran kaki.

\subsection{Rumusan Masalah}

1. Apakah kualitas produk berpengaruh terhadap keputusan pembelian konsumen sepeda motor Honda Beat di Dealer MPM Motor Kalisat-Jember

2. Apakah harga berpengaruh terhadap keputusan pembelian konsumen sepeda motor Honda Beat di Dealer Motor Kalisat-Jember

3. Apakah promosi berpengaruh terhadap keputusan pembelian konsumen sepeda motor Honda beat di Dealer MPM Motor Kalisat-Jember?

\section{LANDASAN TEORI}

Menurut Kotler dan Keller (2009) "Pemasaran adalah proses sosial dan manajerial, dengan proses itu individu dan kelompok mendapatkan apa yang mereka butuhkan dan inginkan dengan menciptakan, menawarkan, dan secara bebas mempertukarkan produk dan 
jasa yang bernilai dengan pihak lain sehingga dapat disimpulkan bahwa pemasaran adalah proses perpindahan barang dan/atau jasa dari produsen ke konsumen, atau semua kegiatan yang berhubungan dengan arus barang dan/atau jasa dari produsen ke konsumen.

\section{Kualitas Produk}

Kualitas produk adalah mencerminkan kemampuan produk untuk menjalankan tugasnya yang mencakup daya tahan, kehandalan atau kemajuan, kekuatan, kemudahan dalam pengemasan dan reparasi produk dan ciri-ciri lainnya (Kotler dan Keller, 2009).

\section{Harga}

Harga menurut Kotler dan Amstrong (2006) adalah sejumlah uang yang ditukarkan untuk sebuah produk atau jasa. Lebih jauh lagi, harga adalah jumlah dari seluruh nilai yang konsumen tukarkan untuk jumlah manfaat dengan memiliki atau menggunakan suatu barang dan jasa.

\section{Promosi}

Menurut (Lamb, C. William Perrealt, dan Mc Charty, 2009) Promosi adalah komunikasi informasi antara penjual dan calon pembeli atau pihak-pihak lain dalam saluran untuk mempengaruhi sikap dan perilaku

\section{Keputusan Pembelian}

Machfoedz (2005) mengemukakan bahwa pengambilan keputusan adalah suatu proses penilaian dan pemilihan dari berbagai alternatif sesuai dengan kepentingan-kepentingan tertentu dengan menetapkan suatu pilihan yang dianggap paling menguntungkan.

Berdasarkan uraian latar belakang, rumusan masalah dan Landasan Teori yang telah dibahas, maka dapat digambarkan kerangka berpikir mengenai hubungan antaran kualitas produk, harga dan promosi sebagai variabel independen atau bebas (X) dengan keputusan pembelian sebagai variabel dependen atau terikat (Y) sebagaimana dapat dilihat pada Gambar 2.1. sebagai berikut:

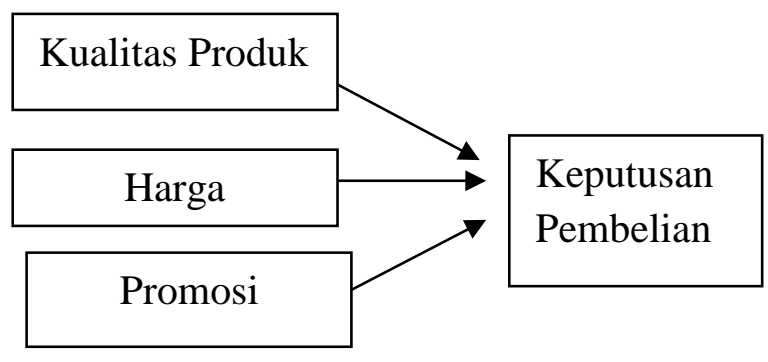

Gambar 2.1. Kerangka Pemikiran

Sumber: Data diolah Tim Peneliti

\section{III.METODE PENELITIAN}

\subsection{Variabel Penelitian}

Variabel penelitian menurut Sugiyono (2008) adalah suatu atribut atau sifat dari orang, obyek atau kegiatan yang memiliki variasi tertentu yang ditetapkan oleh peneliti untuk dipelajari dan ditarik kesimpulannya. Variabel penelitian terdiri dari dua macam, yaitu: variabel terikat (dependent variable) atau variabel yang tergantung pada variabel lainnya, dan variabel bebas (independent variable) atau variabel yang tidak tergantung pada variabel lainnya. 


\subsection{Jenis Dan Sumber Data}

Penelitian ini menggunakan data yang diperoleh melalui responden, dimana responden akan memberikan respon verbal dan respon tertulis sebagai tanggapan atas pernyataan yang diberikan. Data yang digunakan dalam penelitian ini terdiri dari data primer dan sekunder.

\subsection{Populasi dan Sampel}

Menurut Arikunto (2006:130) populasi adalah keseluruhan objek penelitian jika seseorang ingin meneliti semua elemen yang ada pada wilayah penelitian maka penelitiannya merupakan penelitian populasi atau studi populasi atau sensus. Dalam penelitian ini yang menjadi populasi adalah warga Kecamatan Kalisat Kabupaten Jember yang menggunakan motor Honda Beat.

Sampel menurut Arikunto (2006:131) adalah sebagian populasi yang diambil dan dapat mewakili seluruh populasi. Jadi sampel adalah bagian dari populasi. Sampel yang digunakan adalah seluruh populasi yaitu 100 orang dimana disebutkan dalam Arikunto (2006:131) apabila subjek kurang dari 100 orang maka diambil semua.

\subsection{Teknik Pengukuran Data}

Alat yang digunakan dalam penelitian ini adalah kuesioner, yaitu suatu metode pengumpulan data dengan mengajukan daftar pertanyaan kepada responden secara tertulis mengenai pengaruh kualitas produk, harga dan promosi terhadap keputusan pembelian konsumen sepeda motor Honda Beat di Dealer MPM motor kalisat - jember yang di serahkan kepada konsumen untuk di isi dengan menggunakan skala interval yang di susun untuk mengungkapkan sikap sangat setuju, setuju, netral, tidak setuju, sangat tidak setuju terhadap suatu masalah yang diteliti. Dalam hal ini responden di minta tanggapannya terhadap pertanyaan yang diajukan melalui daftar pertanyaan. Skala pengukuran variabel dalam penelitian ini adalah sebagai berikut :
1. Jawaban SS = Sangat Setuju
2. Jawaban $\mathrm{S} \quad=$ Setuju
3. Jawaban $\mathrm{N} \quad=$ Kurang Setuju
4. Jawaban TS = Tidak Setuju
5. Jawaban STS = Sangat Tidak Setuju

\section{IV.PEMBAHASAN}

\subsection{Uji Instrumen Data}

Tabel 4.1 Hasil Pengujian Validitas

\begin{tabular}{ccccc}
\hline \multirow{2}{*}{ No } & Variabel/Indikator & \multicolumn{2}{c}{ Kriteria $\mathbf{1}$} & \multicolumn{1}{c}{ Keterangan } \\
\cline { 2 - 5 } & Kualitas Produk & $\begin{array}{c}\text { Sig. (2- } \\
\text { tailed) }\end{array}$ & $\begin{array}{c}\text { Taraf } \\
\text { signikan }\end{array}$ & \\
$\mathbf{1}$ & $\mathrm{X} 1.1$ & 0,000 & 0,05 & Valid \\
$\mathbf{2}$ & $\mathrm{X} 1.2$ & 0,000 & 0,05 & Valid \\
$\mathbf{3}$ & $\mathrm{X} 1.3$ & 0,000 & 0,05 & Valid \\
& Harga & & & \\
$\mathbf{1}$ & $\mathrm{X} 2.1$ & 0,000 & 0,05 & Valid \\
$\mathbf{2}$ & $\mathrm{X} 2.2$ & 0,000 & 0,05 & Valid \\
$\mathbf{3}$ & $\mathrm{X} 2.3$ & 0,000 & 0,05 & Valid \\
& Promosi & & & \\
\hline
\end{tabular}


Jurnal Manajemen dan Bisnis: Performa Volume XV Nomor 2 September 2018

\begin{tabular}{lcccc}
\hline $\mathbf{1}$ & $\mathrm{X} 3.1$ & 0,000 & 0,05 & Valid \\
$\mathbf{2}$ & $\mathrm{X} 3.2$ & 0,000 & 0,05 & Valid \\
$\mathbf{3}$ & $\mathrm{X} 3.3$ & 0,000 & 0,05 & Valid \\
\hline & Keputusan pembelian & & & \\
$\mathbf{1}$ & $\mathrm{Y} 1$ & 0,000 & 0,05 & Valid \\
$\mathbf{2}$ & $\mathrm{Y} 2$ & 0,000 & 0,05 & Valid \\
$\mathbf{3}$ & $\mathrm{Y3}$ & 0,000 & 0,05 & Valid \\
\hline \multicolumn{4}{r}{} \\
\hline
\end{tabular}

Dari hasil uji validitas instrumen diperoleh bahwa seluruh instrumen memiliki nilai signifikansi lebih kecil dari 5\% atau 0,05 yaitu sebesar 0,000 artinya setiap butir pernyataan layak untuk digunakan (valid) karena persyaratan yang telah terpenuhi.

\subsection{Hasil Uji Reliabilitas}

Tabel 4.2. Hasil Pengujian Reliabilitas

\begin{tabular}{|c|c|c|c|c|}
\hline No & Variabel & $\begin{array}{l}\text { Alpha } \\
\text { hitung }\end{array}$ & $\begin{array}{c}\text { Standar } \\
\text { alpha }\end{array}$ & Keterangan \\
\hline 1. & $\begin{array}{c}\text { Kualitas } \\
\text { Produk } \\
\text { (X1) }\end{array}$ & 0,813 & 0,600 & Reliabel \\
\hline 2. & $\begin{array}{l}\text { Harga } \\
\text { (X2) }\end{array}$ & 0,822 & 0,600 & Reliabel \\
\hline
\end{tabular}

\begin{tabular}{ccccc} 
3. $\begin{array}{c}\text { Promosi } \\
(\mathrm{X} 3)\end{array}$ & 0,838 & 0,600 & Reliabel \\
& 4. $\begin{array}{c}\text { Keputusan } \\
\text { pembelian }\end{array}$ & 0,827 & 0,600 & Reliabel \\
\hline
\end{tabular}

(Y)

Sumber: Data diolah Tim Peneliti

Tampilan output SPSS menunjukkan bahwa hasil perhitungan seluruh variabel memberikan nilai Cronbach's Alpha lebih besar dari 0,60 maka dengan demikian setiap item pertanyaan pada setiap variabel bisa dikatakan reliabel dan siap untuk pengujian selanjutnya.

\subsection{Analisis Regresi Linier Berganda}

Tabel 4.3 Hasil Analisi Regresi Linier Berganda

\begin{tabular}{lcccc}
\hline No. & Variabel & $\begin{array}{c}\text { Koefisien } \\
\text { Regresi }\end{array}$ & $\begin{array}{c}\text { t } \\
\text { hitung }\end{array}$ & Signifikan \\
\hline 1. & Konstanta & 2,526 & 1,992 & 0,049 \\
2. & $\begin{array}{c}\text { Kualitas } \\
\text { Produk } \\
\text { (X1) }\end{array}$ & 0,186 & 2,328 & 0,022 \\
3. & $\begin{array}{c}\text { Harga } \\
\text { (X2) }\end{array}$ & 0,358 & 4,113 & 0,000 \\
4. & $\begin{array}{c}\text { Promosi } \\
\text { (X3) }\end{array}$ & 0,276 & 3,653 & 0,000 \\
\hline \multicolumn{4}{c}{ Sumber: Data diolah Tim Peneliti } \\
\hline
\end{tabular}

Dari persamaan tersebut dapat diartikan bahwa :

a. $b_{1}=0,186$ artinya jika kualitas produk (X1) mengalami peningkatan,dengan asumsi harga (X2), dan promosi (X3) konstan, maka keputusan pembelian mengalami peningkatan. Hal ini juga mengindikasikan bahwa kualitas produk berpengaruh positif terhadap keputusan 
pembelian yang berarti semakin baik kualitas produk akan berdampak pada semakin tingginya keputusan pembelian.

b. $\mathrm{b}_{2}=0,358$ artinya jika harga (X2) mengalami peningkatan dengan asumsi kualitas produk (X1), dan promosi (X3), maka keputusan pembelian mengalami peningkatan. Hal ini juga mengindikasikan bahwa harga berpengaruh positif terhadap keputusan pembelian yang berarti semakin baik harga akan berdampak pada semakin tingginya keputusan pembelian.

c. $b_{3}=0,276$ artinya jika promosi (X3) mengalami peningkatan dengan asumsi kulitas produk (X1), dan harga (X2), maka keputusan pembelian mengalami peningkatan. Hal ini juga mengindikasikan bahwa promosi berpengaruh positif terhadap keputusan pembelian yang berarti semakin baik promosi, maka akan berdampak pada semakin tingginya keputusan pembelian.

\subsection{Hasil Uji t}

Tabel 4.3 Hasil Uji t (Parsial)

\begin{tabular}{clcccc}
\hline No. & Variabel & $\begin{array}{c}\text { Signifikansi } \\
\text { Hitung }\end{array}$ & $\begin{array}{c}\text { Taraf } \\
\text { Signifikansi }\end{array}$ & $\begin{array}{c}\text { t } \\
\text { hitung }\end{array}$ & Keterangan \\
1. & $\begin{array}{l}\text { Kualitas } \\
0,022\end{array}$ & 0,05 & 2,328 & Signifikan \\
& Produk & & & & \\
2. & Harga & 0,000 & 0,05 & 4,113 & Signifikan \\
\hline 3. & Promosi & 0,000 & 0,05 & 3,653 & Signifikan \\
\hline
\end{tabular}

Sumber: Data diolah Tim Peneliti

Dari Tabel 4.3 dapat diketahui bahwa :

a Hasil uji kualitas produk mempunyai nilai signifikansi hitung sebesar 0,022 dan lebih kecil dari 0,05 dan thitung $(2,328)$ yang berarti bahwa kualitas produk mempunyai pengaruh signifikan terhadap keputusan pembelian. Hal ini juga menunjukkan bahwa kualitas produk mempengaruhi keputusan pembelian yang berarti semakin baik kualitas produk akan berdampak pada semakin baiknya keputusan pembelian.

b. Hasil uji harga mempunyai nilai signifikansi sebesar 0,000 dan lebih kecil dari 0,05 dan t hitung $(4,113)$ yang berarti bahwa harga mempunyai pengaruh signifikan terhadap keputusan pembelian. Hal ini juga menunjukkan bahwa harga mempengaruhi keputusan pembelian.

c. Hasil uji promosi mempunyai nilai signifikansi sebesar 0,000 dan lebih kecil dari 0,05 dan t hitung $(3,653)$ yang berarti bahwa promosi mempunyai pengaruh signifikan terhadap keputusan pembelian. Hal ini juga menunjukkan promosi mempengaruhi keputusan pembelian.

\subsection{Uraian Hasil Pengolahan Data}

\subsubsection{Pengaruh Kulaitas Produk Terhadap Keputusan Pembelian}

Penelitian yang dilakukan menunjukkan bahwa nilai koefisien variabel kualitas poduk sebesar 0,186 dengan arah positif dan hasil pengujian hipotesis telah membuktikan terdapat pengaruh kualitas produk terhadap keputusan pembelian. Melalui hasil perhitungan yang telah dilakukan diperoleh taraf signifikansi sebesar 0,022 dan lebih kecil dari 0,05 dan $\mathrm{t}$ hitung $(2,328)$ yang berarti hipotesis diterima. Pengujian secara statistik ini membuktikan bahwa kualitas produk mempunyai pengaruh positif signifikan terhadap keputusan pembelian. Artinya bahwa kualitas produk motor Honda Beat memiliki keandalan produk yang tinggi, dan mempengaruhi keputusan pembelian. Dalam penelitian ini kualitas produk berpengaruh signifikan terhadap keputusan pembelian pada motor Honda Beat, artinya jika 
terjadi peningkatan pada kualitas produk maka akan berpengaruh terhadap keputusan pembelian pada motor Honda Beat.

\subsubsection{Pengaruh Harga Terhadap Keputusan Pembelian}

Penelitian yang dilakukan menunjukkan bahwa nilai koefisien variabel harga sebesar 0,358 dengan arah positif, dan hasil pengujian hipotesis telah membuktikan bahwa Harga mempunyai pengaruh positif terhadap keputusan pembelian. Melalui hasil perhitungan yang telah dilakukan diperoleh taraf signifikansi sebesar 0,000 dan lebih kecil dari 0,05 dan t hitung $(4,113)$ yang berarti harga diterima. Pengujian secara statistik ini membuktikan bahwa harga mempunyai pengaruh positif signifikan harga terhadap keputusan pembelian. Artinya bahwa harga motor Honda Beat terjangkau, sehingga mempengaruhi keputusan pembelian. Dalam penelitian ini harga signifikan terhadap keputusan pembelian pada konsumen yang menggunakan motor Honda Beat, artinya jika harga yang ditetapkan mampu bersaing, maka akan berpengaruh terhadap keputusan pembelian pada motor Honda Beat.

\subsubsection{Pengaruh Promosi Terhadap Keputusaan Pembelian}

Penelitian yang dilakukan menunjukkan bahwa nilai koefisien variabel promosi terhadap keputusan pembelian sebesar 0,276 dengan arah positif dan hasil pengujian hipotesis telah membuktikan terdapat pengaruh desain terhadap keputusan pembelian. Melalui hasil perhitungan yang telah dilakukan diperoleh taraf signifikansi sebesar 0,000 yaitu lebih kecil dari 0,05 dan $t$ hitung $(3,653)$ yang berarti hipotesis diterima. Pengujian secara statistik ini membuktikan bahwa promosi mempunyai pengaruh positif signifikan terhadap keputusan pembelian. Dalam penelitian ini promosi signifikan terhadap keputusan pembelian pada konsumen yang menggunakan motor Honda Beat artinya jika terjadi peningkatan pada promosi maka akan berpengaruh pada keputusan pembelian.

\section{KESIMPULAN}

\subsection{Kesimpulan}

Berdasarkan hasil analisis yang dilakukan, maka kesimpulannya sebagai berikut:

1. Hasil pengujian hipotesis telah membuktikan terdapat hubungan positif dan signifikan Kualitas Produk terhadap keputusan pembelian secara parsial. Hal ini berarti semakin baik Kualitas Produk maka semakin tinggi pula keputusan pembelian.

2. Hasil pengujian hipotesis telah membuktikan terdapat hubungan positif dan signifikan Harga terhadap keputusan pembelian secara parsial. Hal ini berarti semakin baik Harga maka semakin tinggi pula keputusan pembelian.

3. Hasil pengujian hipotesis telah membuktikan terdapat hubungan positif dan signifikan Promosi terhadap keputusan pembelian secara parsial. Hal ini berarti semakin baik Promosi maka semakin tinggi pula keputusan pembelian.

\subsection{Saran}

\subsubsection{Bagi perusahaan}

Hendaknya perusahaan dalam upaya mempertahankan dan meningkatkan keputusan pembelian lebih memperhatikan beberapa variabel yaitu kualitas produk, harga, dan promosi dilihat dari hasil pengolahan data yang didapat melalui penyebaran kuesioner, diperoleh data 
bahwa peranan kualitas produk, harga, dan promosi berpengaruh dominan terhadap keputusan pembelian. sehingga dengan lebih memperhatikan variabel kualitas produk, harga, dan promosi diharapkan akan dapat meningkatkan keputusan pembelian pada motor Honda beat.

\subsubsection{Bagi penelitian selanjutnya}

Diharapkan agar penelitian ini dapat bermanfaat bagi peneliti sehingga dapat memperdalam dan memperbaharui ilmu yang sudah didapatkan

\section{DAFTAR PUSTAKA}

Angipora, Marius. 2002. Dasar-Dasar Pemasaran. Edisi Kedua. PT. Raja Grafindo Persada. Jakarta.

Artika Romal Amrullah. 2016. Pengaruh Kualitas Produk, Harga, Dan Citra Merek Terhadap Keputusan Pembelian Hond BEAT. (STESIA) surabaya.

Augusty Tae Ferdinand. 2006. Metode Penelitian Mananjemen : Pedoman Penelitian untuk Penulisan skripsi, Tesis, dan disertasi Ilmu Manajemen. Badan Penerbit Universitas Diponegoro. Semarang

Basu Swastha, dan Irawan. 2007. Manajemen Pemasaran Modern. Edisi Keduabelas Liberty. Yogyakarta

Darmahesta, B.S. 2006 Manajemen Pemasaran Analisa Perilaku Konsumen, Edisi Kesebelas Cetakan Ketiga BPFE, Yogyakarta

Dimas Pramata 2014. Pengaruh Citra Merek Dan Kulaitas Produk Terhadap Keputusan Pembelian Sepeda Motor yamaha mio J. (studi kasus pada PT yamaha bahana tegal) Universitas Diponegoro

Feigenbaum, A.V. 2000. KendaliMutuTerpadu,Jilid 1, EdisiKetiga, Erlangga, Jakarta

Garvin D.A, 2004. Kualitas Produk : Alat Strategi Yang Penting, Edisi Kesebelas Cetakan Ketiga Erlangga. Jakarta

Imam Ghozali, 2005. Analisis Multivariate SPSS. Badan Penerbit Universitas Diponegoro. Semarang

Jackson R.S Weenas, 2014 Kualitas Produk, Harga dan Kualitas pelayanan terhadap keputusan pembelian spring bet comforta,Universitas Sam Ratulangi Manado

Kotler, Philip dan Gary Amstrong. 2006. Prinsip-Prinsip Pemasaran. edisi Kedelapan. Jilid 2. Erlangga. Jakarta

Kotler, Philip. 2000. Manajemen Pemasaran di Indonesia: Analisis,Perencanaan, implementasi, dan pengendalian. Jakarta: Salemba Empat

Kotler, Philip dan Kevin Lane Keller. 2009. Manajemen Pemasaran Dan Perilaku Konsumen. Edisi Keduabelas. Jilid 1. PT. Indeks. Jakarta

Lamb, C. William Perrealt, dan Mc Charty.2009. Pemasaran. Edisi kesebelas. Penerbit Salemba Empat. Jakarta

Mursid. 2003. Manajemen Pemasaran; dasar, konsep dan strategi. Penerbit PT. Raja Grafindo Persada. Jakarta

Nur Achida 2016. Pengaruh Promosi, Harga dan Desain terhadap keputusan pembelian sepeda motor mio GT, Universitas Pandanaran Semarang 
Nurul Fatmawati A 2017. Kualitas Produk, Citra Merek dan Persepsi Harga terhadap keputusan pembelian sepeda motor metic HONDA, Universitas Stikubank

Sutisna . 2012. Perilaku Konsumen dan Komunikasi Pemasaran.PT. Remaja Rosda Karya. Bandung

Shimp, Terence A. 2003. Periklanan Promosi. Edisi V. Jilid 1\&2. Erlangga. Jakarta

Stanton J, William. 2000. Prinsip Pemasaran Jilid 1. Jakarta : Erlangga

Swastha, Basu , 2008, Manajemen Pemasaran Analisis Perilaku Konsumen, Edisi pertama, Sugiyono. 2005. Metode Penelitian Bisnis. Cetakan Kedelapan. CV Alfabeta. Bandung Sugiyono . 2008. Statistika untuk Penelitian Bisnis. Bandung : Alpfabeta. Bandung T. Hani Handoko. 2002. Manajemen Pemasaran. Edisi Kelima, Liberty. Yogyakarta Tjiptono. 2001. Strategi Pemasaran. Edisi II. Penerbit Andi. Yogyakarta 